University of Nebraska - Lincoln

DigitalCommons@University of Nebraska - Lincoln

$9-14-2017$

\title{
Genomics Symposium: Translational genomics to improve fertility of animals
}

M. A. Mirando

Institute of Food Production and Sustainability, mmirando@nifa.usda.gov

Follow this and additional works at: https://digitalcommons.unl.edu/usdaarsfacpub

Mirando, M. A., "Genomics Symposium: Translational genomics to improve fertility of animals" (2017). Publications from USDA-ARS / UNL Faculty. 1838.

https://digitalcommons.unl.edu/usdaarsfacpub/1838

This Article is brought to you for free and open access by the U.S. Department of Agriculture: Agricultural Research Service, Lincoln, Nebraska at DigitalCommons@University of Nebraska - Lincoln. It has been accepted for inclusion in Publications from USDA-ARS / UNL Faculty by an authorized administrator of DigitalCommons@University of Nebraska - Lincoln. 


\title{
GENOMICS SYMPOSIUM: Translational genomics to improve fertility of animals ${ }^{1}$
}

\author{
M. A. Mirando ${ }^{2}$ \\ Division of Animal Systems, Institute of Food Production \\ and Sustainability, USDA National Institute of Food and Agriculture, Washington, DC 20250-2240
}

(C) 2017 American Society of Animal Science. All rights reserved. J. Anim. Sci. 2017.95:4194-4195

doi:10.2527/jas2017.1902

In 2010, the USDA National Institute of Food and Agriculture (NIFA) launched the Agriculture and Food Research Initiative (AFRI) Food Security Challenge Area program. The goal of this program was to support integrated research, extension, and education projects directed at increasing the agricultural production of plants and animals (Mirando et al., 2012) needed to feed a burgeoning global population that is expected to be almost 9.8 billion people by the year 2050 (United Nations, Department of Economic and Social Affairs, Population Division, 2017). One program area in the 2010 AFRI Food Security Challenge Area request for applications (RFA) focused on increasing production efficiency in livestock through funding of integrated research, extension, and education project grants that fostered collaboration of scientists and educators working in the field of genetics and genomics with those in other disciplines, including animal nutrition, health, and reproduction. Animal-focused AFRI programs to be offered over the next 2 yr were also described. In 2012, the AFRI Food Security Challenge Area RFA solicited grant applications for the "Translational Genomics for Improved Fertility of Animals" program, and NIFA subsequently awarded 4 grants totaling US\$10,125,583 to project directors originally located at the University of Nebraska (D. C. Ciobanu),

\footnotetext{
${ }^{1}$ A symposium held at the Joint Annual Meeting July 19-23, 2016, Salt Lake City, UT, with publication sponsored by the Journal of Animal Science, the American Society of Animal Science, and the USDA National Institute of Food and Agriculture. The author thanks A. M. Turzillo (USDA National Institute of Food and Agriculture) and the four speakers from this symposium for their critical review of the manuscript.

${ }^{2}$ Corresponding author: mmirando@nifa.usda.gov

Received July 9, 2017.

Accepted July 17, 2017.
}

the University of Missouri (J. F. Taylor), Texas A\&M University (P. J. Pinedo), and Washington State University (T. E. Spencer).

Results emanating from grants awarded in the 2012 "Translational Genomics for Improved Fertility of Animals" program were presented at the Genomics Symposium titled "Translational Genomics to Improve Fertility of Animals" held at the Joint Annual Meeting of the American Dairy Science Association, the American Society of Animal Science (ASAS), the Canadian Society of Animal Science, and the Western Section of the ASAS in Salt Lake City, UT, July 19 to 24,2016 . The symposium began with a presentation by D. C. Ciobanu, who discussed results from his AFRI grant titled "Translational genomics for improving sow reproductive longevity" (Wijesena et al., 2017). He described work in which genetic variants associated with age at puberty and litter size traits were identified using genome-wide association studies and transcriptional profiling. Results indicated that gilts attaining puberty at an earlier age were more likely to have increased reproductive longevity as sows. The long-term goal is to identify functional SNP with large effects on fertility traits that can be used to select replacement gilts for improved reproductive performance and increased longevity.

The next presentation, by J. F. Taylor (University of Missouri, Columbia), focused on identifying variants in the bovine genome that are lethal to embryonic survival. Taylor et al. (2016) reported on the development of the first generation of a bovine functional assay containing 170,000 variants, of which $>120,000$ have the potential to be functional and 34,000 are common variants present on many of the genotyping assays currently used for genotyping in the cattle industry as part of their AFRI grant titled "Identification and management of alleles impairing heifer fertility while optimizing genetic gain in Angus cattle." The assay, GGP-F250, is now pub- 
licly available from GeneSeek (Neogen Corporation, Lansing, MI). Using this assay, the authors have genotyped 18,300 cattle representing Holstein and 9 U.S. beef breeds. Results from this research will assist with mating decisions and lead to improved fertility in both the dairy and beef cattle industries.

The third presentation, by G. L. M. Rosa (University of Wisconsin-Madison), described results from the AFRI grant "Genomic selection for improved fertility of dairy cows with emphasis on cyclicity and pregnancy" (Rosa et al., 2016). Holstein cattle $(12,000)$ from 7 states were monitored for uterine health, estrous cyclicity, estrus, pregnancy rate, pregnancy loss, metabolic disorders, and milk yield. Extensive analysis of the phenotypic data using pedigree information has been performed to estimate genetic parameters, such as heritability of each trait and genetic correlations between them. In addition, a reproductive index, predicting probability of pregnancy at first AI after calving, was developed and used in selective genotyping of high-fertility cows (i.e., pregnant after first AI) and low-fertility cows (i.e., not pregnant after $2 \mathrm{AI}$ ). The project team described plans to continue identifying fertility indicators as well as detect genomic regions affecting fertility in dairy cattle.

The final presentation was made by T. E. Spencer (University of Missouri, Columbia), who discussed the AFRI grant titled "Improving fertility of dairy cattle using translational genomics" (Spencer et al., 2016). The overarching goal of this project is to improve the fertility of lactating dairy cows through marker-assisted genetic selection for maternal fertility in both heifers and cows combined with use of sires with high daughter pregnancy rate. The project team members have identified genomic loci associated with fertility in heifers and primiparous lactating dairy cattle and contributed educational content on the genomics of reproduction in both English and Spanish to the DaireXNET website (http://articles.extension.org/dairy_cattle; accessed 9 July 2017).
In summary, presentations at the Genomics Symposium at the 2016 Joint Annual Meeting described results of research funded through the 2012 AFRI Food Security "Translational Genomics for Improved Fertility of Animals" program and thus provided a constructive forum for discussing the application of translational genomics to improve fertility in swine, beef cattle, and dairy cattle. Although projects are still ongoing, the presentations revealed substantial progress toward application of genomic approaches to enhance reproductive performance of animals.

\section{LITERATURE CITED}

Mirando, M. A., J. M. Bewley, J. Blue, D. M. Amaral-Phillips, V. A. Corriher, K. M. Whittet, N. Arthur, and D. J. Patterson. 2012. Extension Education Symposium: Reinventing extension as a resource - What does the future hold? J. Anim. Sci. 90:3677-3692. doi:10.2527/jas.2011-5074

Rosa, G. J. M., P. J. Pinedo, J. E. P. Santos, R. C. Bicalho, G. Schuenemann, R. Chebel, K. N. Galvão, R. O. Gilbert, S. L. Rodrigez-Zas, C. M. Seabury, J. Fetrow, and W. W. Thatcher. 2016. Genomic selection for improved fertility of dairy cows with emphasis on cyclicity and pregnancy. J. Anim. Sci. 94(E-Suppl. 5):331. (Abstr.)

Spencer, T. E., H. L. Neibergs, P. J. Hansen, J. B. Cole, J. Dalton, D. A. Moore, M. Chahine, and A. De Vries. 2016. Improving fertility of dairy cattle using translational genomics. J. Anim. Sci. 94(E-Suppl. 5):325-326. (Abstr.)

Taylor, J. F., R. D. Schnabel, B. Simpson, J. E. Decker, M. Rolf, B. P. Kinghorn, A. Van Eenennaam, M. D. MacNeil, D. S. Brown, M. F. Smith, and D. J. Patterson. 2016. Detection and selection against early embryonic lethals in US beef breeds. J. Anim. Sci. 94(E-Suppl. 5):331. (Abstr.)

United Nations, Department of Economic and Social Affairs, Population Division. 2017. World population prospects: Key findings \& advance tables: 2017 revision. https://esa.un.org/ unpd/wpp/Publications/Files/WPP2017_KeyFindings.pdf. (Accessed 9 July 2017.)

Wijesena, H. R., C. A. Lents, J.-J. Riethoven, M. D. TrenhaileGrannemann, J. F. Thorson, B. N. Keel, P. S. Miller, M. L. Spangler, S. D. Kachman, and D. C. Ciobanu. 2017. Using genomic approaches to uncover sources of variation in age at puberty and reproductive longevity in sows. J. Anim. Sci. (in press.) doi:10.2527/jas2016-1334 